\title{
Effect of the addition of young bamboo culm flour as a sugar and/or fat substitute in cookie formulations
}

\author{
Mária Herminia Ferrari FELISBERTO ${ }^{1}$, Patricia Satie Endo MIYAKE ${ }^{1}$, Antonio Ludovico BERALDO², \\ André Rinaldi FUKUSHIMA ${ }^{3,4}$ (D), Luís Antônio Baffile LEONI ${ }^{3}$, Maria Teresa Pedrosa Silva CLERICI ${ }^{1 *}$ (D)
}

\begin{abstract}
One of the innovation strategies of the bakery industry is the use of new ingredients capable of increasing the health appeal of products. The objective of this study was to evaluate the effect of partial substitution (15\%) of wheat flour by young bamboo culm flour (YBCF) in cookies formulations, using a central composite design with two variables (sugar and fat reductions) and three replicates at the central point. Formulations were selected by surface response methodology $(p<0.10)$ and evaluated over 28 days of storage for stability and nutritional composition. Only sugar reduction led to significant differences in the diameter of the cookies. Formulations with 50\% of reduction of sugar and fat (F2 and F3, respectively) were selected for the study, in addition to a control formulation (CF). Moisture content and water activity of the cookies remained low throughout the storage, as recommended for the maintenance of the crispness. Cookies F2 and F3 were light-colored, similar to CF, and presented lower energy value ( 0.83 and $11.73 \%$, respectively), compared with CF. These results indicate that YBCF may be a promising ingredient for the bakery industry, once it contains high fiber levels and allows the reduction of up to $50 \%$ sugar and fat in cookies.
\end{abstract}

Keywords: bamboo flour; healthy products; new ingredient.

Practical Application: Young bamboo culm flour may be an alternative ingredient for healthier foods formulations.

\section{Introduction}

The cookies production in Brazil ranked fifth among the top cookies producing countries, with a production of 1.3 million tons in 2015, and per capita consumption of $6.01 \mathrm{~kg}$ per year, surpassed only by Argentina, the United Kingdom, Italy, and United States (Associação Brasileira das Indústrias de Biscoitos, Massas Alimentícias e Pães \& Bolos Industrializados, 2015). This product is highly consumed by different audiences, due to its long shelf-life and ease of consumption, and especially by children, due to the sweet taste and perfect crisp texture (Moraes et al., 2010; Feddern et al., 2011).

Cookies can be defined as baked cereal-based products containing high sugar and fat levels, moisture content from 2 to $8 \%$, and water activity ranging from 0.1 to 0.3 . Thus, the quality of the ingredients used in cookies formulation has a direct influence on the characteristics of the final product (Gökmen et al., 2008; Pareyt et al., 2009).

The sugar reduction in cookies can affect the texture, flavor, sweetness, color, and the conservation of the product as it assists in maintaining the moisture content constant, so that the cookie does not gain moisture from the environment, and do not lose its crunchiness (Manley, 2011). The fat reduction can affect dough lubrication, thus impairing the mixing step, volume, color, stability or shelf life of the processed products. Fat is one of the basic components of cookies formulation, found at relatively high levels, up to 60\% (Cauvain \& Young, 2006; Manley, 2011). It contributes to the production of softer and shorter cookies, while sugar contributes to the increase in cookies diameter and crispness (Cauvain \& Young, 2006; Manley, 2011). This is the great challenge of the bakery industry since both cannot be easily replaced, especially in the complex structure of cookies (Pareyt et al., 2009).

Consumers' concern about maintaining health and preventing certain diseases has contributed to increasing the market demand for healthier, low-fat, low-sugar, and fiber-containing products, especially bakery products, which are consumed in large quantities in a daily routine, with an important role in human nutrition (Martins et al., 2017).

Choudhury et al. (2015) reported that replacing up to $10 \%$ wheat flour for bamboo shoot fiber in cookies formulations enhanced the nutraceutical and functional properties due to the presence of phenolic compounds, fibers, proteins, and vitamin C. Farris et al. (2008) evaluated the water retention capacity of bamboo shoot fiber in Amaretti biscuits, which contains almond flour rather than wheat flour, and found that

${ }^{1}$ Departamento de Tecnologia de Alimentos, Faculdade de Engenharia de Alimentos, Universidade Estadual de Campinas - UNICAMP, Cidade Universitária Zeferino Vaz, Campinas, SP, Brasil

${ }^{2}$ Faculdade de Tecnologia, Universidade Estadual de Campinas - UNICAMP, Limeira, SP, Brasil

${ }^{3}$ Universidade São Judas Tadeu - USJT, Campus Mooca, São Paulo, SP, Brasil

${ }^{4}$ Departamento de Patologia, Faculdade de Veterinária e Zootecnia - FMVZ, Universidade de São Paulo - USP, Cidade Universitária, São Paulo, SP, Brasil

*Corresponding author: mclerici@unicamp.br 
the addition of fiber limited the sugar crystallization, maintaining the traditional texture characteristics of the product after 10 days of storage. However, before using bamboo shoots in food formulations, they must be previously submitted to appropriate treatment, as is done with cassava, which goes through the drying/ roasting process (Cereda, 2003), since they also present in its composition cyanogenic glycosides, linamarin and taxifilina, which are compounds that can form hydrocyanic acid (about $1000 \mathrm{mg} / \mathrm{kg}$ ) (Satya et al., 2010; Satya et al., 2012). Therefore, it is expected that these compounds content decrease with the growth of the culm, so the young bamboo culm may present a lower content of these toxic compound.

When evaluating the effect of the addition of bamboo shoot fiber and the processing conditions (time and temperature) of Amaretti biscuits, Farris \& Piergiovanni (2008) observed that the addition of fiber, associated with oven time and temperature, increased hardness of the biscuits. However, the authors suggested a greater addition of fiber to improve the mouthfeel as well as the overall quality of the product.

However, it is worth mentioning that increasing the production of bamboo shoot fiber for use in human consumption can alter the sustainability of bamboo clumps, once it is possible to collect only $20 \%$ to $30 \%$ shoots per year (Pereira \& Beraldo, 2016). Thus, alternative sources of fiber are required, and the young bamboo culm can be a raw material of great potential, as it allows a greater fiber yield when compared to bamboo shoots (Felisberto et al., 2017).

Some young bamboo culm species have been highlighted not only by the high potential for extraction of starches and fibers (Felisberto et al., 2017), but also by their sugar content, including the species Dendrocalamus asper specie, which presents on average $9 \%$ sugar in the young culms. Although this specie is of Asian origin, it is cultivated in Brazil (in the cities of Jacareí and Mogi das Cruzes/SP) for the production of both canned and in natura bamboo shoots. Therefore, it is noticed that the bamboo shoot chain is already well established, while the young culm is still little explored, since its use is restricted to building materials, furniture and handicrafts, with limited shelf life due the attack of powder-post beetles, which is attracted by the starch.

A young culm from the variety $D$. asper specie can reach $40 \mathrm{~m}$ in height and up to $20 \mathrm{~cm}$ in diameter (Liese \& Kohl, 2015), and contains high levels of starch and fibers. Thus, the culm of this specie may be an industrial source of young bamboo culm flour, contributing for using the whole plant.

Considering that the search for potential food ingredients has been a strong trend, the use of young bamboo culm flour may be an interesting alternative for the development of healthier products using new ingredients, besides contributing with the sustainability and longevity of bamboo clumps. Thus, the objective of the study was to evaluate the technological and nutritional properties of cookies formulations, with partial substitution of wheat flour for young bamboo culm flour from $D$. asper specie, with reduced sugar and/or fat content.

\section{Materials and methods}

\subsection{Raw materials}

The young bamboo culm flour (YBCF) from $D$. asper specie was obtained in a previous study carried out by our research group (Felisberto et al., 2017) (International Organization for Standardization, 2007). The young culms were collected, divided into three parts (bottom, middle, and top), cut into smaller pieces, treated with sodium metabisulphite solution (200 ppm/1 h), and dried in an oven $\left(50{ }^{\circ} \mathrm{C} / 72 \mathrm{~h}\right)$. Then, the material was ground in a knife mill to obtain a homogeneous flour. All the other ingredients were purchased from the same batch in the local market of Campinas (SP).

\subsection{Characterization of wheat flour and young bamboo culm flour}

YBCF was evaluated for the presence of total cyanogenic heteroside compounds, according to Fox \& Robyt (1991), with some adaptations. The method is known as the Konigi method and uses the U.V.-VIS spectrophotometry technique. The method is based on the reduction of sodium picrate by cyanide to form a colored product, which is measured in a colorimeter at $530 \mathrm{~nm}$. In the validation process, this method had a lower detection limit of $5 \mathrm{ppm}$ and a lower limit of quantification of $10 \mathrm{ppm}$ cyanide, with a $2 \% \mathrm{SD}$, showing a stable color resistant to other components. The validation was performed using the same parameters proposed by Fox \& Robyt (1991), with an adaptation of the matrix effect to young bamboo culm flour. Both wheat flour and YBCF from D. asper specie were characterized for proximate composition, according to Association of Official Analytical Chemists (1998) for moisture (method 44-15.02), proteins (method 46-13.01) and ash (method 08-01.01) contents. Total fiber (method 992-16) and lipids (method 920.39) contents were determined according to American Association of Cereal Chemists (2010), while digestible carbohydrates were calculated by difference [100- (moisture + lipids + proteins + ash + total fiber)].

\subsection{Experimental design}

A factorial design with two variables $\left(2^{2}\right.$ - sugar and margarine reductions) and three replicates at the central point was used, totaling 7 formulations (Table 1). In all formulations, a partial

Table 1. Factorial design $2^{2}$ with three central points of the cookies formulations.

\begin{tabular}{cccccc}
\hline \multirow{2}{*}{ Formulations } & \multicolumn{2}{c}{$\begin{array}{c}\text { Coded } \\
\text { Levels }\end{array}$} & & \multicolumn{2}{c}{ Real Levels $(\%)^{1}$} \\
\cline { 2 - 3 } \cline { 5 - 6 } & $\mathbf{X}_{1}$ & $\mathbf{X}_{2}$ & & Sugar reduction & Fat reduction \\
\hline F1 & -1 & -1 & & 0 & 0 \\
F2 & +1 & -1 & & 50 & 0 \\
F3 & -1 & +1 & & 0 & 50 \\
F5 & +1 & +1 & & 50 & 50 \\
F6 & 0 & 0 & & 25 & 25 \\
F7 & 0 & 0 & & 25 & 25 \\
\hline${ }^{1}$ Percentage reduction of $x$ (sugar) and $x$ (margarine) of each formulation
\end{tabular}

${ }^{1}$ Percentage reduction of $\mathrm{x}_{1}$ (sugar) and $\mathrm{x}_{2}$ (margarine) of each formulation. 
substitution (15\%) of wheat flour for young bamboo culm flour was performed. Formulations without reduction of both, sugar and fat contents (F5, F6 and F7) are considered as the central point and control formulation of first part of the experiment.

\subsection{Manufacture of cookies}

The formulation of Clerici et al. (2013) was used as a base, with some changes in the amount of ingredients (in relation to $100 \%$ wheat flour), as follows: $54.60 \%$ sugar, $38 \%$ margarine, $9.4 \%$ egg yolk, $0.15 \%$ vanilla essence, $0.36 \%$ condiments (nutmeg, clove powder, and cinnamon powder), $0.61 \%$ salt, $2.5 \%$ ammonium bicarbonate, and $17.65 \%$ maize starch. Two mixing stages were used for the cookies manufacture. First, sugar, fat, egg yolk, and vanilla essence were creamed in a high-speed planetary mixer (Kitchen aid, St Joseph, USA) for 5 minutes. The other ingredients were then added and homogenized for approximately one minute at a low speed. Water was added to the optimal absorption level so that dough reached the optimum development over 3 minutes of mixing at a medium speed. The optimum development of the dough is the point at which all ingredients have been properly incorporated, and the dough is homogeneous and at an optimum point, which allows the biscuits to be molded. The dough was then rolled out to $5 \mathrm{~mm}$ thick sheets, cut into cylinders $38 \mathrm{~mm}$ in diameter, and baked for about 7 minutes in a hearth oven, model HF4B (Haas, Curitiba, Brazil), at surface and ceiling temperatures of $\sim 200^{\circ} \mathrm{C}$ and $220^{\circ} \mathrm{C}$, respectively. Afterwards, the cookies were cooled for 30 minutes, vacuum-packed and stored at room temperature, protected from light, until analysis.

\section{Technological characterizations of the cookies}

\subsection{Diameter, thickness, weight loss, and specific volume}

The diameter and thickness of the cookies were measured using a pachymeter, and the specific volume was calculated by the ratio between the apparent volume and the cookies' weight after baking, according to the methodology of American Association of Cereal Chemists (2010). The weight loss was calculated as a ratio between raw dough and baked cookies' weight. The apparent volume was measured by the seed displacement method, according to AACCI (method 10-05.01, 2010). All analyses were performed on 10 cookie samples.

\subsection{Moisture}

Moisture content was determined according to the methodology of the Association of Official Analytical Chemists (1998) (method 44-15.02).

\subsection{Water activity (aw)}

Water activity (aw) was determined by the water activity meter using a dew point sensor (Aqualab, 4TEV, Decagon, Pullman, USA), and the readings were performed at room temperature $\left(25^{\circ} \mathrm{C}\right)$.

\subsection{Instrumental texture}

Texture of the cookies was determined using the TA-XT Plus texture analyser (Stable Micro Systems, England) using a $50 \mathrm{~kg}$ load cell, equipped with a three-point bend rig (HDP/3PB) and heavy duty platform. Maximum force was recorded as the hardness value and test conditions were: pre-test speed of $1 \mathrm{~mm} / \mathrm{s}$, test speed of $3 \mathrm{~mm} / \mathrm{s}$, post-test speed of $10 \mathrm{~mm} / \mathrm{s}$, and penetration distance of $5 \mathrm{~mm}$. The readings were performed on 10 cookie samples.

\subsection{Color measurements}

The color parameters $\left(\mathrm{L}^{*}, \mathrm{a}^{*}\right.$, and $\left.\mathrm{b}^{*}\right)$ were evaluated according to the CIELab system, in a colorimeter CR-400 (Konica Minolta, Japan), using illuminant D65 and observer angle $2^{\circ}$, and the readings were performed using three replicates per sample.

\subsection{Statistical analysis to select the cookies}

Data were evaluated by the Response Surface Methodology to calculate the regression coefficients, followed by analysis of variance (ANOVA), at a significance level of $10 \%$ with a minimum coefficient $\left(\mathrm{R}^{2}\right)$ of 0.7 , using the software Statistica (version 8.0). The formulations whose diameter does not vary with the reduction of fat and with the reduction of the sugar content of the formulation were selected.

\subsection{Proximate composition of the selected cookies}

The selected cookies were characterized for the proximate composition as described above for wheat flour and YBCF. The energy value was calculated considering the energy conversion factors: $9 \mathrm{kcal} / \mathrm{g}$ for lipids, $4 \mathrm{kcal} / \mathrm{g}$ for proteins, and $4 \mathrm{kcal} / \mathrm{g}$ for carbohydrates. A formulation without sugar and/or fat reduction, with no substitution of wheat flour for the young bamboo culm flour was used as control (CF).

\subsection{Technological characterization and stability of the selected cookies}

The moisture contents, aw, texture, and color parameters were determined for the selected cookies and the control formulation, as described above, at days $1,7,14,21$, and 28 of storage.

\subsection{Statistical analysis of the selected cookies}

The results of the proximate composition and the technological characterization were obtained at least in triplicate and evaluated by difference among the formulations, through analysis of variance (ANOVA), at a significance level of 5\%, followed by the ScottKnott test, using the statistical program SISVAR, version 5.6.

\section{Results and discussion}

\subsection{Characterization of the raw materials}

The wheat flour for home use contains $12.57 \pm 0.06 \mathrm{~g} / 100 \mathrm{~g}$ moisture; $0.64 \pm 0.01 \mathrm{~g} / 100 \mathrm{~g}$ lipids; $10.92 \pm 0.11 \mathrm{~g} / 100 \mathrm{~g}$ protein; $0.42 \pm 0.05 \mathrm{~g} / 100 \mathrm{~g}$ ash; $3.50 \pm 0.29 \mathrm{~g} / 100 \mathrm{~g}$ total fiber; and $71.95 \%$ comprising digestible carbohydrates. Young bamboo culm flour (YBCF) has $5.37 \pm 0.05 \mathrm{~g} / 100 \mathrm{~g}$ moisture; $0.29 \pm 0.00 \mathrm{~g} / 100 \mathrm{~g}$ lipids; $1.27 \pm 0.05 \mathrm{~g} / 100 \mathrm{~g}$ protein; $1.07 \pm 0.05 \mathrm{~g} / 100 \mathrm{~g}$ ash; $72.23 \pm 0.35 \mathrm{~g} / 100 \mathrm{~g}$ total fiber; and $19.77 \mathrm{~g} / 100 \mathrm{~g}$ comprising digestible carbohydrates. YBCF presented a cyanogenic content 
lower than the detection limit (5 ppm) of the Konigi method, which means that its consumption does not represent health risks.

It is observed that the wheat flour exhibited a typical chemical composition of wheat flour for home use, with other carbohydrates as the main component ( $>70 \mathrm{~g} / 100 \mathrm{~g})$. However, according to Manley (2011), flours with protein content around $11 \%$ present ideal conditions for the development of a stronger gluten network, which is indicated for the preparation of cream cracker biscuits. Therefore, we chose to use starch $(17.65 \%)$ in the cookies formulations, to dilute the flour proteins and allow the development of a weaker and more extensible gluten network, with minimal changes in texture, crispness, and shape of the cookies.

Young bamboo culm flour had fiber as the major component $(>70 \mathrm{~g})$. This result was higher than that observed in flours from other plants, such as eggplant flour (44 g/100 g) (Perez \& Germani, 2004) and flours of cabbage stalks and spinach culms (36 and $49 \mathrm{~g} / 100 \mathrm{~g}$, respectively) (Mauro et al., 2010).

Moreover, the young bamboo culm flour was light-colored, with a lightness $\left(\mathrm{L}^{*}\right)$ higher than 80 , which does not affect the coloring of the final product, according to International Organization for Standardization (2007); thus it can be used as fiber-rich ingredient.

\subsection{Technological characterization of the cookies}

Table 2 shows all technological parameters of the cookies, and Table 3 presents the coefficients generated in the response surface analysis. A significant difference was observed only for the effect of the independent variable $\mathrm{x} 1$ (sugar reduction) on the parameter diameter, where it was possible to observe a reduction in cookies diameter as an effect of the reduction of the sugar content of the formulation.

The formulation F3 presented the highest mean diameter ( $43.45 \mathrm{~mm}$ ), that is, they exhibited a higher expansion, probably due to the $50 \%$ reduction in fat content. We observed in the present study that, for the formulation used, the effect of the reduction of the fat content was not significant in reducing the spreadability of the cookies. This fact must have occurred, due to the concentration of the sugar content, since we use the simple reduction of the fat content without replacement by another ingredient, which led to an increase in sugar concentration in the final formulation content. And according to Bertolino \& Braga (2017), the larger expansion observed on cookies may be due to the use of finer-grained sugar rather than granulated sugar, since more water is available in the formulation. They also report that variations in cookies' size may lead to adjustments in packaging by the food industry, which is designed with a maximum variation of $2 \%$, and should be avoided due to the increase in costs.

In relation to the thickness (Table 2), it increased after baking, from 5 to $10.78 \mathrm{~mm}$, which was expected due to the gases produced during heating, by the decomposition of ammonium bicarbonate (ammonia and carbon dioxide). Ammonia gas is responsible for improving the expansion of the cookies by changing the protein structure due to the passage of the gas through its porous structure. The weight loss was, on average, $17 \%$. The cookies presented an average specific volume of $2.54 \mathrm{~mL} / \mathrm{g}$, moisture content of $6.09 \mathrm{~g} / 100 \mathrm{~g}$, and aw of 0.48 . Regarding the color parameters, the cookies were very light-colored, with values of $73.27,5.16,28.20$ for the parameters $L^{*}, a^{*}$, and $b^{*}$, respectively, corresponding to the region of light yellowish brown.

Moraes et al. (2010) also found an increase in diameter after baking of cookies containing higher sugar levels. Even without the addition of fibers to the formulations, the authors found an increase in thickness after baking, from 5 to $8.76 \mathrm{~mm}$ thick, weight loss of $16 \%$, hardness around $55 \mathrm{~N}$, and color parameters very close to the values observed in the present study $\left(\mathrm{L}^{*}=67.63\right.$, $\mathrm{a}^{\star}=8.33$, and $\left.\mathrm{b}^{\star}=27.09\right)$.

Choudhury et al. (2015) elaborated cookies containing $0,5,10$, and $15 \%$ bamboo shoot flour, and observed that diameter and thickness decreased after baking, for the formulations containing higher fiber levels. However, cookies were darker when compared to cookies of the present study, with $L^{*}$ values ranging from 54.10 to 36.31 .

\subsection{Selection of the cookies}

The response surface analysis (Figure 1) indicated significant differences in cookies' diameter only for the variable sugar reduction, once the lower the sugar content ( 0 to $50 \%$ reduction), the smaller the cookies' diameter ( 35.75 to $41.09 \mathrm{~mm}$ ). In contrast, no significant differences were observed for the variable fat content. The results showed that it was possible to produce cookies with a reduction of $50 \%$ fat (F3), without affecting the technological characteristics.

Thus, two formulations were produced, F2 and F3, with the highest levels of sugar and fat reduction, respectively, together with a control formulation (CF), without the replacement of wheat flour by YBCF and without sugar and fat reduction (Table 1), to compare the proximate composition and the technological characteristics.

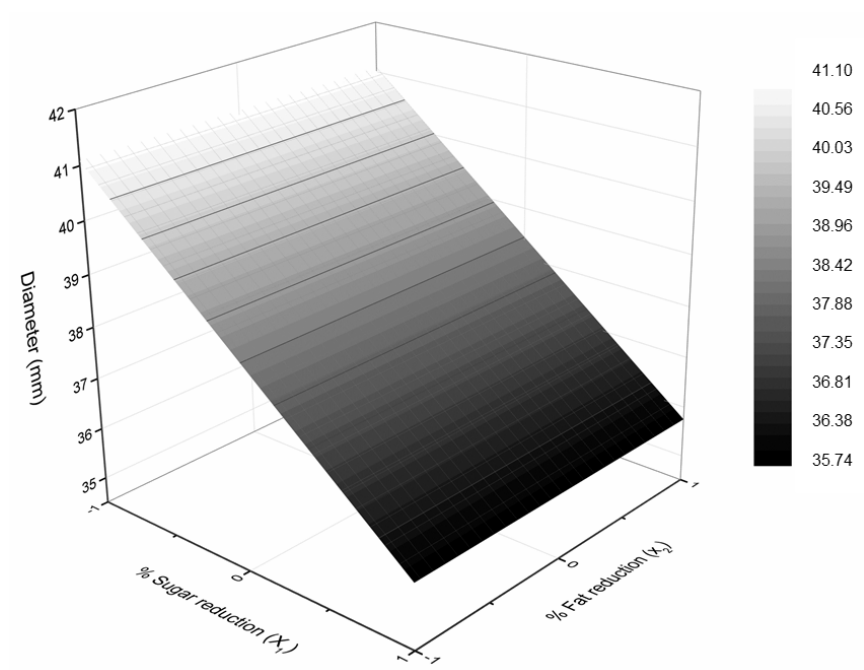

Figure 1. Response surface analysis of the cookies with sugar and fat reduction $(\mathrm{p}<0.10)$. 
Felisberto et al.

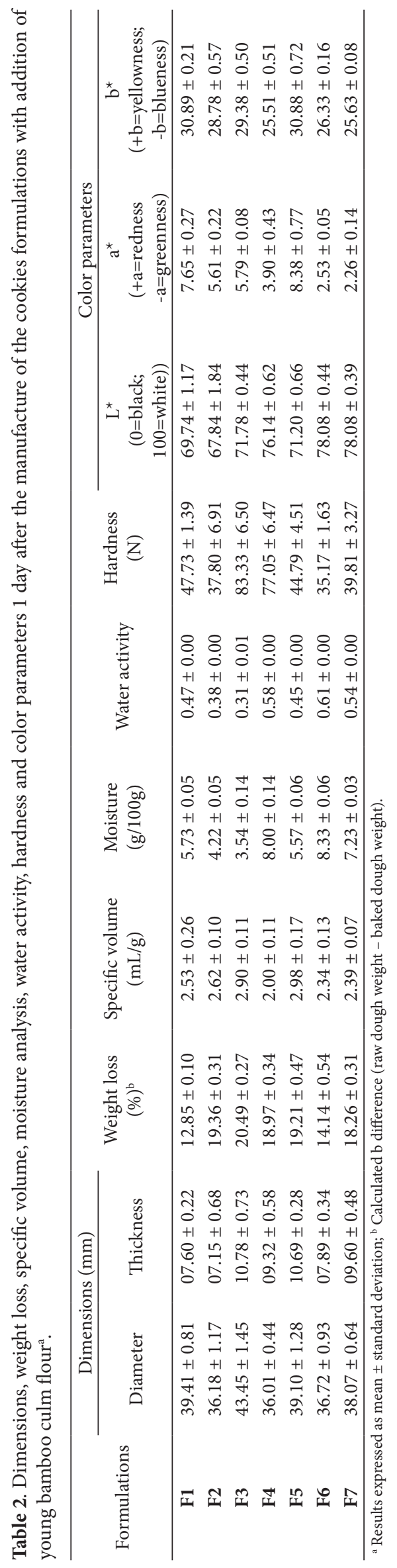


The control cookies (CF) and those selected in the experimental design (F2 and F3) are shown in Figure 2. The cookies F2 and F3 have a smaller diameter than CF (44.89 $\mathrm{mm})$, which was expected due to the lower amount of ingredients that affect the cookies' expansion, such as sugar and fat.

Regarding to the proximate composition of the selected cookies - All cookies (CF, F2, and F3) were evaluated for moisture content, lipids, protein, ash, total fiber, and digestible carbohydrates, and the results are presented in Table 4 . Low moisture values were observed for all cookies $(<6 \mathrm{~g} / 100 \mathrm{~g})$, with the lowest values for those with sugar reduction (F2). In spite of the significant changes during the 28 days of storage and among the different cookies (Table 5), the moisture content remained between 2 and 5\%, which confers the characteristic crispness to the product, according to Sarantópoulos et al. (2001).

The lower fat content was observed in F3, and differences were observed, such as higher protein and ash contents, with the addition of YBCF when compared to the CF. Significant differences were also observed for fiber contents among the formulations, with values $>7 \mathrm{~g} / 100 \mathrm{~g}$ for both the formulations F2 and F3, which was expected since the YBCF contained $>70 \mathrm{~g} / 100 \mathrm{~g}$. In addition, cookies of the F3 formulation could be considered as a source of fiber since they presented fiber content higher than $2.5 \mathrm{~g}$ in a $30 \mathrm{~g}$ portion, as recommended by Brasil (2012). These results corroborate the great potential of YBCF as an alternative raw material, rich in fibers. Regarding the energy value, a significant reduction in F3 was observed, which presented about $10 \%$ less calories when compared to CF and F2.

\subsection{Technological characterization and stability of the selected cookies}

Table 5 presents the results of the cookies after $1,7,14,21$, and 28 days of storage for moisture, aw, hardness, and color parameters $\left(\mathrm{L}^{\star}, \mathrm{a}^{\star}\right.$, and $\left.\mathrm{b}^{\star}\right)$.

Table 3. Response surface analysis ${ }^{\mathrm{a}}$.

\begin{tabular}{|c|c|c|c|c|c|}
\hline & Parameters & Mathematical model & Mean Value & $\mathrm{R}^{2}$ & p-value \\
\hline Diameter & & $Y=38.42-2.6675 x_{1}$ & - & 70.14 & 0.018 \\
\hline Thickness & & ns & 09.00 & 63.53 & 0.330 \\
\hline Weight loss & & ns & 17.61 & 69.73 & 0.255 \\
\hline Specific volume & & ns & 02.54 & 62.11 & 0.347 \\
\hline Moisture & & ns & 06.09 & 57.56 & 0.404 \\
\hline Water activity & & ns & 00.48 & 58.14 & 0.397 \\
\hline Hardness & & ns & 52.24 & 63.56 & 0.330 \\
\hline \multirow[t]{3}{*}{ Color parameters } & $\mathrm{L}^{\star}(0=$ black; $100=$ white $)$ & ns & 73.27 & 36.94 & 0.664 \\
\hline & $a^{\star}(+a=$ redness $;-a=$ greenness $)$ & ns & 05.16 & 20.63 & 0.851 \\
\hline & $\mathbf{b}^{\star}(+\mathbf{b}=$ yellowness; $-\mathbf{b}=\mathbf{b l u e n e s s})$ & ns & 28.20 & 46.03 & 0.551 \\
\hline
\end{tabular}

${ }^{\mathrm{a}} \mathrm{ns}=$ not significant.

Table 4. Proximate composition of the control (CF) and selected formulations (F2 and F3) .

\begin{tabular}{|c|c|c|c|c|c|c|c|}
\hline \multirow{2}{*}{\multicolumn{2}{|c|}{$\begin{array}{l}\text { Formulations }^{\mathrm{b}} \\
\text { Moisture }\end{array}$}} & \multicolumn{5}{|c|}{ Proximate composition (g/100 g) } & \multirow{3}{*}{$\begin{array}{c}\begin{array}{c}\text { Calories } \\
(\mathrm{kcal} / 100 \mathrm{~g})\end{array} \\
443.30\end{array}$} \\
\hline & & \multirow{2}{*}{$\begin{array}{c}\text { Lipid } \\
4.86 \pm 0.40^{\mathrm{b}}\end{array}$} & \multirow{2}{*}{$\frac{\text { Protein }}{7.69 \pm 0.09^{\mathrm{b}}}$} & \multirow{2}{*}{$\frac{\text { Ash }}{0.42 \pm 0.03^{\mathrm{b}}}$} & \multirow{2}{*}{$\begin{array}{c}\text { Total fiber } \\
1.94 \pm 0.32^{c}\end{array}$} & \multirow{2}{*}{$\begin{array}{c}\begin{array}{c}\text { Digestible } \\
\text { carbohydrates }\end{array} \\
69.70\end{array}$} & \\
\hline CF & $5.39 \pm 0.08^{\mathrm{a}}$ & & & & & & \\
\hline F2 & $4.97 \pm 0.08^{\mathrm{b}}$ & $8.11 \pm 0.01^{\mathrm{a}}$ & $8.32 \pm 0.07^{\mathrm{a}}$ & $0.63 \pm 0.02^{\mathrm{a}}$ & $7.13 \pm 0.08^{\mathrm{b}}$ & 60.84 & 439.63 \\
\hline F3 & $5.50 \pm 0.06^{\mathrm{a}}$ & $9.78 \pm 0.14^{\mathrm{c}}$ & $6.98 \pm 0.01^{\mathrm{c}}$ & $0.42 \pm 0.05^{\mathrm{b}}$ & $8.48 \pm 0.12^{\mathrm{a}}$ & 68.84 & 391.30 \\
\hline
\end{tabular}

${ }^{a}$ Results expressed as means \pm standard deviation. Means followed by different letters in the same column differ significantly ( $\left.<<0.05\right)$ by Scott-Knott test. ${ }^{b}$ Control Formulation $(\mathrm{CF})$, cookies with $50 \%$ of sugar reduction (F2) and $50 \%$ of fat reduction (F3). ${ }^{c}$ Calculated by difference $[100-($ moisture + lipid + protein + ash + total fiber) $]$.

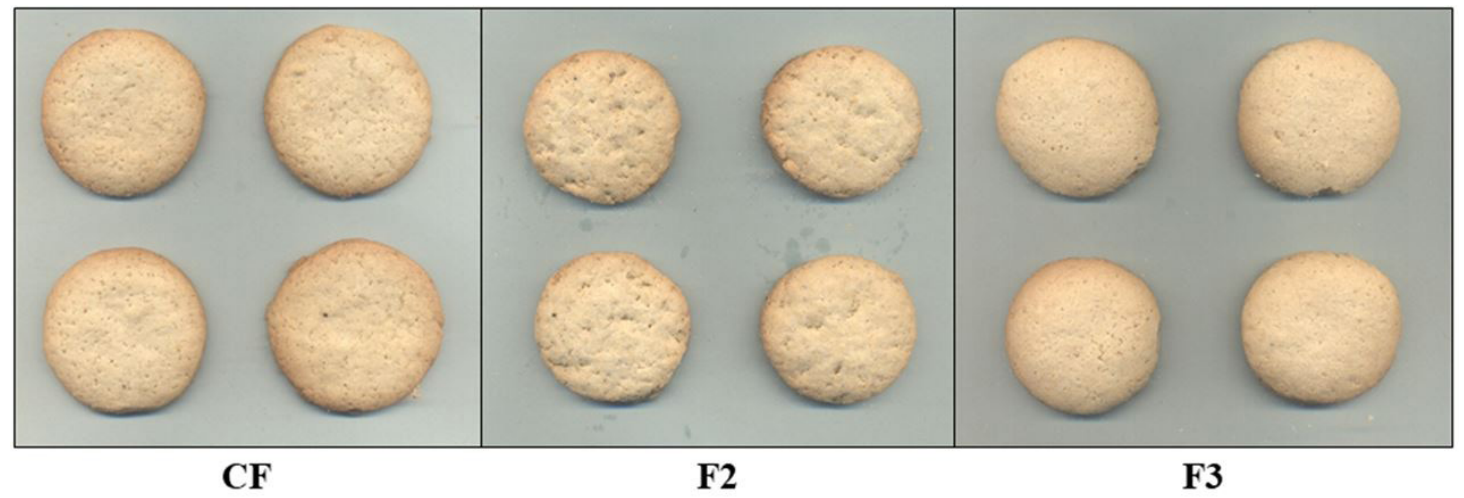

Figure 2. Control formulation (CF) and cookies with 50\% of sugar reduction (F2) and 50\% of fat reduction (F3). 
Table 5. Technological characterization and stability of the control (CF) and selected formulations (F2 and F3) at days 1, 7, 14, 21 and 28 after the manufacture ${ }^{\mathrm{a}}$.

\begin{tabular}{|c|c|c|c|c|c|c|c|}
\hline \multirow{2}{*}{\multicolumn{2}{|c|}{ Analysis }} & \multirow{2}{*}{ Formulations $^{\mathrm{b}}$} & \multicolumn{5}{|c|}{ Days } \\
\hline & & & 1 & 7 & 14 & 21 & 28 \\
\hline \multirow{3}{*}{\multicolumn{2}{|c|}{ Moisture (g/100 g) }} & $\mathrm{CF}$ & $02.43 \pm 0.04^{\mathrm{Ce}}$ & $02.72 \pm 0.00^{\mathrm{Cc}}$ & $02.89 \pm 0.13^{\mathrm{Cb}}$ & $002.60 \pm 0.07^{\mathrm{Cd}}$ & $03.09 \pm 00.05^{\mathrm{Ba}}$ \\
\hline & & F2 & $04.22 \pm 0.05^{\mathrm{Aa}}$ & $04.27 \pm 0.04^{\mathrm{Aa}}$ & $00.77 \pm 0.03^{\mathrm{Ac}}$ & $004.02 \pm 0.04^{\mathrm{Ab}}$ & $04.13 \pm 00.07^{\mathrm{Ab}}$ \\
\hline & & F3 & $03.54 \pm 0.14^{\mathrm{Bb}}$ & $03.32 \pm 0.03^{\mathrm{Bc}}$ & $03.02 \pm 0.04^{\mathrm{Bd}}$ & $003.38 \pm 0.02^{\mathrm{Bc}}$ & $04.16 \pm 00.02^{\mathrm{Aa}}$ \\
\hline \multirow{3}{*}{\multicolumn{2}{|c|}{ Water activity (aw) }} & $\mathrm{CF}$ & $00.20 \pm 0.00^{\mathrm{Cd}}$ & $00.25 \pm 0.00^{\mathrm{Cc}}$ & $00.26 \pm 0.00^{\mathrm{Cb}}$ & $000.28 \pm 0.00^{\mathrm{Ca}}$ & $00.29 \pm 00.00^{\mathrm{Ca}}$ \\
\hline & & F2 & $00.38 \pm 0.00^{\mathrm{Aa}}$ & $00.35 \pm 0.00^{A c}$ & $00.37 \pm 0.00^{\mathrm{Ab}}$ & $000.37 \pm 0.00^{\mathrm{Ab}}$ & $00.39 \pm 00.00^{\mathrm{Aa}}$ \\
\hline & & F3 & $00.31 \pm 0.01^{\mathrm{Bb}}$ & $00.29 \pm 0.00^{\mathrm{Bc}}$ & $00.28 \pm 0.00^{\mathrm{Bd}}$ & $000.31 \pm 0.00^{\mathrm{Bb}}$ & $00.34 \pm 00.00^{\mathrm{Ba}}$ \\
\hline \multirow{3}{*}{\multicolumn{2}{|c|}{ Hardness (N) }} & $\mathrm{CF}$ & $36.27 \pm 2.35^{\mathrm{Ba}}$ & $30.20 \pm 3.65^{\mathrm{Cb}}$ & $28.80 \pm 2.15^{\mathrm{Cb}}$ & $025.12 \pm 2.34^{\mathrm{Cc}}$ & $29.93 \pm 03.21^{\mathrm{Cb}}$ \\
\hline & & F2 & $36.03 \pm 6.91^{\mathrm{Ba}}$ & $38.14 \pm 3.53^{\mathrm{Ba}}$ & $39.34 \pm 7.07^{\mathrm{Ba}}$ & $036.37 \pm 3.69^{\mathrm{Ba}}$ & $42.28 \pm 06.11^{\mathrm{Ba}}$ \\
\hline & & F3 & $85.30 \pm 6.50^{\mathrm{Ab}}$ & $87.54 \pm 7.97^{\mathrm{Ab}}$ & $63.06 \pm 11.94^{\mathrm{Ac}}$ & $110.94 \pm 9.11^{\mathrm{Aa}}$ & $78.85 \pm 10.19^{\mathrm{Ab}}$ \\
\hline \multirow{9}{*}{$\begin{array}{l}\text { Color } \\
\text { parameters }\end{array}$} & \multirow{3}{*}{$\begin{array}{l}L^{*}(0=\text { black; } \\
100=\text { white })\end{array}$} & $\mathrm{CF}$ & $75.08 \pm 0.42^{\mathrm{Aa}}$ & $73.72 \pm 0.71^{\mathrm{Aa}}$ & $70.37 \pm 0.54^{\mathrm{Ab}}$ & $075.67 \pm 0.80^{\mathrm{Aa}}$ & $76.64 \pm 00.75^{\mathrm{Aa}}$ \\
\hline & & F2 & $67.84 \pm 1.84^{\mathrm{Cc}}$ & $73.73 \pm 0.90^{\mathrm{Aa}}$ & $71.01 \pm 0.90^{\mathrm{Ab}}$ & $073.82 \pm 0.48^{\mathrm{Aa}}$ & $75.47 \pm 00.78^{\mathrm{Aa}}$ \\
\hline & & F3 & $71.78 \pm 0.44^{\mathrm{Bb}}$ & $75.56 \pm 0.74^{\mathrm{Aa}}$ & $72.45 \pm 1.33^{\mathrm{Ab}}$ & $075.17 \pm 0.23^{\mathrm{Aa}}$ & $75.05 \pm 00.26^{\mathrm{Aa}}$ \\
\hline & \multirow{3}{*}{$\begin{array}{l}a^{\star}(+a=\text { redness; } \\
-\mathbf{a}=\text { greenness })\end{array}$} & $\mathrm{CF}$ & $03.52 \pm 0.15^{\mathrm{Bc}}$ & $04.75 \pm 0.29^{\mathrm{Ab}}$ & $05.47 \pm 0.63^{\mathrm{Aa}}$ & $002.72 \pm 0.13^{\mathrm{Bc}}$ & $03.03 \pm 00.25^{\mathrm{Cc}}$ \\
\hline & & F2 & $05.61 \pm 0.22^{\mathrm{Aa}}$ & $04.50 \pm 0.16^{\mathrm{Ab}}$ & $04.17 \pm 0.20^{\mathrm{Bb}}$ & $004.25 \pm 0.27^{\mathrm{Ab}}$ & $03.97 \pm 00.05^{\mathrm{Bb}}$ \\
\hline & & F3 & $05.79 \pm 0.08^{\mathrm{Aa}}$ & $04.41 \pm 0.12^{\mathrm{Ab}}$ & $04.62 \pm 0.24^{\mathrm{Bb}}$ & $004.62 \pm 0.02^{\mathrm{Ab}}$ & $05.74 \pm 00.05^{\mathrm{Aa}}$ \\
\hline & \multirow{3}{*}{$\begin{array}{l}\mathbf{b}^{\star}(+\mathbf{b}=\text { yellowness; } \\
-\mathbf{b}=\text { blueness })\end{array}$} & $\mathrm{CF}$ & $28.16 \pm 1.26^{\mathrm{Ab}}$ & $29.45 \pm 0.45^{\mathrm{Aa}}$ & $29.63 \pm 0.79^{\mathrm{Aa}}$ & $026.37 \pm 0.29^{\mathrm{Bc}}$ & $26.12 \pm 00.30^{\mathrm{Cc}}$ \\
\hline & & F2 & $28.78 \pm 0.57^{\mathrm{Ab}}$ & $29.96 \pm 0.19^{\mathrm{Aa}}$ & $28.15 \pm 0.24^{\mathrm{Bb}}$ & $028.84 \pm 0.69^{\mathrm{Ab}}$ & $28.62 \pm 00.32^{\mathrm{Bb}}$ \\
\hline & & F3 & $29.38 \pm 0.50^{\text {Аa }}$ & $28.00 \pm 0.27^{\mathrm{Bb}}$ & $27.70 \pm 0.30^{\mathrm{Bb}}$ & $028.13 \pm 0.28^{\mathrm{Ab}}$ & $29.80 \pm 00.30^{\mathrm{Aa}}$ \\
\hline
\end{tabular}

${ }^{a}$ Results expressed as means \pm standard deviation. Means followed by different upper-case letters overlapped in the same column for each parameter differ significantly (p<0.05) by Scott-Knott test. Means followed by different lowercase letters overlapped in the same row, for each formulation, differ significantly (p<0.05) by Scott-Knott test. ${ }^{b}$ Control formulation (CF), cookies with $50 \%$ of sugar reduction (F2) and $50 \%$ of fat reduction (F3).

Although an increase in moisture content was observed at the end of the storage, F2 and F3 showed a significant reduction at days 14 and 7, and 14, respectively. In addition, a higher moisture content was observed in F2 at day 1, which was observed in F3 only on the last day of storage. It is also worth mentioning that both formulations containing YBCF had a higher moisture content at the end of storage when compared to the control. Despite sugar and fat being responsible for the retention of moisture in cookies, through the results obtained for a higher moisture content in cookies made with YBCF, we observed that in this case, fiber was responsible for retaining moisture, probably due to the interaction of the bamboo fiber with other ingredients, like starch (from addition and from wheat flour).

Similar behavior was observed for aw, with a drop from days 7 to 14 , and an increase until the end of the storage, when all cookies exhibited aw $<0.6$. As reported by Clerici et al. (2013), a lower aw is required to maintain the cookies' crispness, as observed in the formulations F2, F3, and CF. In addition, F2 presented the highest values during all the storage period, which may be due to its lower fat content. Although the lower moisture and aw values, they are in the optimum range to maintain the crispness (moisture and aw lower than 5\% and 0.65, respectively), as reported by Manley (2011).

With respect to the hardness of the cookies, a variation was observed during storage, and F3 was the formulation that presented the greatest increase in the hardness of the biscuits throughout the storage time. It happens, probably, due to the reduced fat content since it is primarily responsible for the aeration of the product. The air entrapped in the mass acts as a nucleus for the growth gases and for the release of water vapor during baking. As a result the cookies would present an increased volume, texture more uniform and soft, making the cookies more easily breakable (Pareyt et al., 2009). However, despite the significant differences, a similar hardness value was observed for the reduced-sugar cookies (F2) when compared to the control.

Similar results were observed by Moraes et al. (2010), who evaluated low-fat cookies and obtained higher tensile strength values $(66.65 \mathrm{~N})$ when compared to the cookies of the present study. These results reinforce the role of fat on dough lubrication and aeration, as reported by Pareyt et al. (2009), evidencing the effect of the YBCF associated with fat reduction on the texture of the cookies, increasing the hardness of the product.

Regarding the color parameter, the cookies CF, F2, and F3 were in the region of yellowish brown. An increase in $\mathrm{L}^{*}$ value was observed over time, which decreased from day 7 to 14 and subsequently increased for all cookies, with no significant differences among the formulations at the end of storage $\left(L^{*}=75.72\right)$. Similar results (72.80 to 76.93$)$ were observed by Marangoni (2007), who partially replaced wheat flour for yacon flour and oat flakes in functional Champurrada cookies.

Although some oscillations were observed for the coordinates $\mathrm{a}^{\star}$ and $\mathrm{b}^{*}$ during the storage, a decrease in $\mathrm{a}^{\star}$ value was observed, while $b^{\star}$ values remained or decreased (CF) when compared to day 1 . This result shows that although the cookies had lower intensity of red and yellow shades over time, they remained in the slightly yellowish region.

\section{Conclusion}

The results showed that young bamboo culm flour may be an interesting ingredient to reduce sugar in cookies, without compromising the texture characteristics of the product, besides 
reducing the energy value. The use of this flour also increased the nutritional contribution of fibers when compared to the control formulation, allowing to meet the consumer's demand for healthier fiber-rich products.

\section{Acknowledgements}

The authors are grateful to FAEPEX and FAPESP for the scholarship of Patricia S. E. Miyake (2016/13533-5) and for the financial support (2015/19637-4); CAPES for the support of the graduate program and for the scholarship of Mária H. F. Felisberto, CNPq and SAE/UNICAMP for the scholarship of the students who supported along the project.

\section{References}

American Association of Cereal Chemists - AACCI. (2010). Approved Methods of Analysis. St. Paul: AACC International.

Associação Brasileira das Indústrias de Biscoitos, Massas Alimentícias e Pães \& Bolos Industrializados - ABIMAPI. (2015). Estatísticas de Biscoitos. São Paulo: ABIMAPI. Retrieved from http://www.abimapi. com.br/estatistica-biscoito.php

Association of Official Analytical Chemists - AOAC. (1998). Official methods of analysis. Arlington: AOAC.

Bertolino, M. T., \& Braga, A. (2017). Ciência e tecnologia para fabricação de biscoitos - handbook do biscoiteiro (1. ed.). São Paulo: Livraria Varela/Revista Higiene Alimentar.

Brasil. Ministério da Saúde. Agência Nacional de Vigilância Sanitária - ANVISA. (2012, Novembro 12). Dispõe sobre o Regulamento Técnico sobre Informação Nutricional Complementar (RDC $\mathrm{n}^{\circ}$ 54, de 12 de Novembro de 2012). Diário Oficial [da] República Federativa do Brasil.

Cauvain, S., \& Young, L. (2006). Baked products: science, technology and practice. Oxford: Blackwell Publishing. http://dx.doi. org/10.1002/9780470995907.

Cereda, M. P. (2003). Tecnologia, usos e potencialidades de tuberosas amiláceas latino americanas São Paulo: Fundação Cargill.

Choudhury, M., Badwaik, L. S., Borah, P. K., Sit, N., \& Deka, S. C. (2015). Influence of bamboo shoot powder fortification on physicochemical, textural and organoleptic characteristics of biscuits. Journal of Food Science and Technology, 52(10), 6742-6748. http://dx.doi. org/10.1007/s13197-015-1709-3. PMid:26396424.

Clerici, M. T. P. S., Oliveira, M. E., \& Nabeshima, E. H. (2013). Qualidade física, química e sensorial de biscoitos tipo cookies elaborados com a substituição parcial da farinha de trigo por farinha desengordurada de gergelim. Brazilian Journal of Food Technology, 16(2), 139-146. http://dx.doi.org/10.1590/S1981-67232013005000017.

Farris, S., \& Piergiovanni, L. (2008). Effects of ingredients and process conditions on 'Amaretti' cookies characteristics. International Journal of Food Science \& Technology, 43(8), 1395-1403. http://dx.doi. org/10.1111/j.1365-2621.2007.01648.x.

Farris, S., Piergiovanni, L., \& Limbo, S. (2008). Effect of bamboo fibre and glucose syrup as new ingredients in the manufacture of Amaretti cookies. Italian Journal of Food Science, 20(1), 75-90.

Feddern, V., Durante, V. V. O., Miranda, M. Z., \& Salas-Mellado, M. M. (2011). Avaliação física e sensorial de biscoitos tipo cookie adicionados de farelo de trigo e arroz. Brazilian Journal of Food Technology, 14(4), 267-274. http://dx.doi.org/10.4260/BJFT2011140400032.

Felisberto, M. H. F., Miyake, P. S. E., Beraldo, A. L., \& Clerici, M. T. P. S. (2017). Young bamboo culm: Potential food as source of fiber and starch. Food Research International, 101(Suppl. C), 96-102. http://dx.doi.org/10.1016/j.foodres.2017.08.058. PMid:28941702.

Fox, J. D., \& Robyt, J. F. (1991). Miniaturization of three carbohydrate analyses using a microsample plate reader. Analytical Biochemistry, 195(1), 93-96. http://dx.doi.org/10.1016/0003-2697(91)90300-I. PMid:1888021.

Gökmen, V., Serpen, A., Açar, Ö. Ç., \& Morales, F. J. (2008). Significance of furosine as heat-induced marker in cookies. Journal of Cereal Science, 48(3), 843-847. http://dx.doi.org/10.1016/j.jcs.2008.06.007.

International Organization for Standardization - ISO. (2007). 6647-2: Rice: Determination of amylose content Part 2: Routine methods. Geneva: ISO.

Liese, W., \& Kohl, M. (2015). Bamboo - The plant and its uses (1. ed.). Switzerland: Springer International Publishing.

Manley, D. (2011). Manley's technology of biscuits, crackers and cookies (4th ed.). Cambridge: Woodhead Publishing. http://dx.doi. org/10.1533/9780857093646.

Marangoni, A. L. (2007). Potencialidade de aplicação de farinha de Yacon (Polymnia sonchifolia) em produtos à base de cereais (Dissertação de mestrado). Universidade Estadual de Campinas, Campinas.

Martins, Z. E., Pinho, O., \& Ferreira, I. M. P. L. V. O. (2017). Food industry by-products used as functional ingredients of bakery products. Trends in Food Science \& Technology, 67(Suppl. C), 106128. http://dx.doi.org/10.1016/j.tifs.2017.07.003.

Mauro, A. K., Silva, V. L. M., \& Freitas, M. C. J. (2010). Caracterização física, química e sensorial de cookies confeccionados com Farinha de Talo de Couve (FTC) e Farinha de Talo de Espinafre (FTE) ricas em fibra alimentar. Food Science and Technology, 30(3), 719-728. http://dx.doi.org/10.1590/S0101-20612010000300024.

Moraes, K. S., Zavareze, E. R., Miranda, M. Z., \& Salas-Mellado, M. M. (2010). Avaliação tecnológica de biscoitos tipo cookie com variações nos teores de lipídio e de açúcar. Food Science and Technology, 30(1), 233-242. http://dx.doi.org/10.1590/S0101-20612010000500036.

Pareyt, B., Talhaoui, F., Kerckhofs, G., Brijs, K., Goesaert, H., Wevers, M., \& Delcour, J. A. (2009). The role of sugar and fat in sugar-snap cookies: Structural and textural properties. Journal of Food Engineering, 90(3), 400-408. http://dx.doi.org/10.1016/j.jfoodeng.2008.07.010.

Pereira, M. A. R., \& Beraldo, A. L. (2016). Bambu de corpo e alma (2. ed.). Bauru: Canal 6.

Perez, P. M. P., \& Germani, R. (2004). Farinha mista de trigo e berinjela: características físicas e químicas. B. CEPPA, 22(1), 15-24.

Sarantópoulos, C. I. G. L., Oliveira, L. M., \& Canavesi, E. (2001). Requisitos de conservação de alimentos em embalagens flexíveis. Campinas: CETEA/ITAL.

Satya, S., Bal, L. M., Singhal, P., \& Naik, S. N. (2010). Bamboo shoot processing: food quality and safety aspect (a review). Trends in Food Science \& Technology, 21(4), 181-189. http://dx.doi.org/10.1016/j. tifs.2009.11.002.

Satya, S., Singhal, P., Bal, L. M., \& Sudhakar, P. (2012). Bamboo shoot: a potential source of food security. Mediterranean Journal of Nutrition and Metabolism, 5(1), 1-10. http://dx.doi.org/10.1007/ s12349-011-0086-3. 